\title{
THE RELATIONSHIP BETWEEN SHYNESS AND MOTIVATION TO SPEAK ENGLISH OF THE FIRST YEAR STUDENTS OF ENGLISH STUDY PROGRAM OF FKIP UIR PEKANBARU
}

\author{
Marhamah \\ Islamic University of Riau \\ email: marhamahahmadhamid@gmail.com
}

\begin{abstract}
The objectives of this research are (1) to find out if there is a relationship between shyness and motivation to speak English of the first year students of English study program of FKIP UIR Pekanbaru, (2) to know their shyness and their motivation to speak in speaking English of the first year students of English Study Program of FKIP UIR Pekanbaru, and (3) to know how the relationship between shyness and motivation to speak in speaking English of the first year students of English Study Program of FKIP UIR Pekanbaru. Shyness means a feeling about oneself in a presence of other. Motivation is process of stimulating peple to action $t$ accomplish desired goals. In this research, motivation to speak means to stimulate students to speak English. There are two variables in this research. Shyness is taken as an independent variable and motivation to speak is taken as a dependent variable. The total population of the first year students is about 154. So, the sample of this research is 25 students. The instrument of this research is questionnaire. The aspects of students' shyness are (1)worry about their think of them, (2) become shy to deal with people from a different social class or to work with more skilled people, and (3) avoid social gathering and usually speak in low voice. The aspect of students' motivation to speak English are integrative and instrumental motivation.

Based on the result of the analysis, there are only $40 \%$ of the students that were indeed shy. It can be concluded that there is significant relationship between students' shyness and their motivation $t$ speak English.
\end{abstract}

Keywords: shyness, motivation, motivation to speak, speaking

\section{HUBUNGAN ANTARA RASA MALU DAN MOTIVASI UNTUK BERBICARA BAHASA INGGRIS PADA MAHASISWA SEMESTER PERTAMA DI PROGRAM STUDI PENDIDIKAN BAHASA INGGRIS UNIVERSITAS ISLAM RIAU PEKANBARU}

\begin{abstract}
Abstrak
Tujuan penelitian ini adalah (1) untuk mengetahui hubungan antara rasa malu dan motivasi untuk berbicara bahasa Inggris mahasiswa semester satu Program Studi Bahasa Inggris FKIP UIR Pekanbaru, (2) untuk mengetahui rasa malu dan motivasinya dan (3) untuk mengetahui bagaimana hubungan antara rasa malu dan motivasi untuk berbicara bahasa Inggris. Rasa malu adalah suatu perasaan seseorang dengan kehadiran orang lain. Sedangkan motivasi adalah proses stimulasi atau tanggapan seseorang kepada tindakan untuk memenuhi tujuan yang diinginkan. Dalam penelitian ini, motivasi untuk berbicara adalah untuk menstimulasi atau menganngapi mahasiswa untuk berbicara bahasa Inggris. Terdapat dua variabel pada penelitian ini. Rasa malu


adalah variabel bebas dan motivasi untuk berbicara adalah variable terikat. Jumlah total populasi nya adalah 154 orang. Jadi, sampelnya seramai 25 orang. Adapun instrumen penelitian ini adalah angket. Aspek rasa malu terdiri dari 3 macam yaitu (1) khawatir terhadap pemikiran orang lain terhadap dirinya, (2) menjadi malu berhubungan dengan orang-orang yang berbeda kelas sosialnya atau yang bekerja dengan yang orang-orang yang memiliki kemampuan lebih dari dirinya, dan (3) menghindari kebersamaan dan biasanya berbicara dengan nada suara yang rendah. Sedangkan aspek motivasi untuk berbicara bahasa Inggris adalah motivasi terpadu dan motivasi instrumen.

Berdasakan hasil analisis, terdapat hanya $40 \%$ mahasiswa yang malu. Hal ini dapat diambil kesimpulan bahwa ada hubungan antara rasa malu dan motivasinya untuk berbicara bahasa Inggris diantara mahasiswa semester satu program studi Pendidikan Bahasa Inggris tahun akademik 2014/2015. Semakin tinggi rasa malu mereka maka semakin rendah motivasi berbicaranya.

Kata Kunci : rasa malu, motivasi, motivasi untuk berbicara, berbicara

\section{INTRODUCTION}

Speaking is one $\mathrm{f}$ the four language skills. The purpose of speaking is to convey an idea or message to the listener. To be able to speak correctly, one must know all sorts of language rules. In order to avoid miscommunication among speakers and listeners, we have to learn grammar, vocabulary, and pronunciation.

Speaking is productive skill, Widdowson (1984) states communication through speaking is commonly performed in face to face and occure as parts of dialogue. The ideas of speaking itself cannot be communication unless what is being said is received and understood by another person. Speaking is oral interaction where the participants need to negotiate the meaning contained in ideas, feelings and information and manage in terms of who is to say what, to whom and about what. there are six points that she or he must think simultaneously, those are, deciding what she or he wants to say, selecting the appropriate words to convey the meaning and the pattern she or he is going to use, using the correct arrangement of sound voice, pitch and

J-SHMIC, Vol 3, No 2, August 2016 forms, making sure that she or he wants to say in the appropriate situation, placing her tongue and lips in certain position.

According to Bowen (1985) there are some aspects that have great influence in speaking were needed, such as: (1) pronunciation, (2) vocabulary, and (3) grammar. In pronunciation, there are three aspects that students should mastery, that is, sounds, stress and intonation/rhythm. If one of them does not run smoothly, it can cause misunderstanding. Beside, it seems vocabulary plays an important role in speaking. We can not ignore them while we are studying in speaking. Students should have more than 500 words in their mind and they should know when the word is used. In grammar, actually, grammar is not the only contribution factor. There are some other aspects which facilitate the process of acquiring a language, for instance, the method used by the teacher, the number of vocabulary processed by the students.

In fact, in the English Study Program of FKIP UIR Pekanbaru, some of the students tend to be shy in speaking English in front of the class even though the students

The Relationship between Shyness and Motivation to Speak English of the First Year Students of English Study Program of FKIP UIR Pekanbaru 
have learned English from Elementary school up t Senior High School. They are still unable to express their ideas by speaking or making conversation with friends in front of the class. It means that they still have difficulties to express their ideas, thought and feeling. This might happen because of their feeling of shyness themselves. They are shy because they have no self-confidence. The writer knows that many of the students are shy in speaking. Half of them can communicate by using English but they are shy $t$ speak or make conversation with friends. Among them only few students are able to speak. The other half can be classified as passive students.

Based on writer's personal observation and experience, she found some reasons why they are passive in speaking or making conversation with friends. They worried about what other think of them in answering the questions during teaching and learning in classroom and they do not have any confidence in themselves. In speaking class, the general aim of speaking class is to enable the students to express their opinion in English. However, since English is not our language, it is hard for them to achieve it. They tend to be shy in which they feel other students have more skill in speaking English. They are also afraid of making a mistake when they spoke. Students who have high motivation in speaking probably would use English in any situation whether in the classroom or outside the classroom. It can be concluded that students who have a low level of shyness appraise themselves positively and are always optimistic and creative in the learning process of speaking. The higher the level of shyness, the lower the motivation to speak English students have, and the lower the level of shyness, the higher the motivation to speak in speaking English will become.

J-SHMIC, Vol 3, No 2, August 2016
The above facts are dealing with the motivation problems that often happen to students that have low motivation. It seems that their motivation to communicate does not show their expectancy to engage well in the process of speaking English. That's why shyness and motivation to speak are very closely tied.

Actually, shyness refers to passivity, emotional arousal, and excessive self-focus in the presence of other people ( Jones, Cheek, and Briggs 1986). It also frequently involves negative self-evaluations, social avoidance, and withdrawal. From a practical point of view, the importance of shyness derives from its consequences. Shy persons, for example, are often excessively uncomfortable and anxious in social situations. Moreover, because of such discomfort, chronic shyness often leads to failures to capitalize on the occupational and interpersonal opportunities available to the shy person. Scientifically, shyness affords the opportunity to observe the complex interplay of personal and situational context factors in the evolution of social interactions. (Encyclopedia.com : 2015).

Addison Wesley (1990) stated that shyness as "discomfort, inhibition, and awkwardness in social situation, especially with people who are not familiar". Zimbardo (2014) described shyness as a problem characterized by anxiety, low self-esteem, inadequate social skills, and feeling of selfconsciousness. Rochelle (1993) states that shyness is uncomfortable emotion. It means that shyness appears because of the presence of someone else. In fact, someone does not want someone else to know his weaknesses. It happens because he or she has a low level of self-esteem. It is a manifestation of sense of shyness. Rochelle (1993) states shyness is the feeling of someone in unreal behavior or outward behavior while she or he is facing

The Relationship between Shyness and Motivation to Speak English of the First Year Students of English Study Program of FKIP UIR Pekanbaru 
other people whom just be known. It happens because she/he has lack of selfconfidence, low self-esteem and unreal or outward behavior. She was feel reluctant other, because of this, she/he tends to be shy. According to Lyness (2013) Shyness is an emotion that affects how a person feels and behaves around others. Shyness can mean feeling uncomfortable, self-conscious, nervous, bashful, timid, or insecure. People who feel shy sometimes notice physical sensations like blushing or feeling speechless, shaky, or breathless. Shyness is the opposite of being at ease with yourself around others. When people feel shy, they might hesitate to say or do something because they're feeling unsure of themselves and they're not ready to be noticed. In adition, shy people are anxious about themselves all the time. They can not think about other people's feeling very much because they are worried about themselves and what others are thinking about them. They think other people are more intelligent and can $\mathrm{d}$ everything better. They think people are more attractive. They believe others have more knowledge. Shy people get very anxious when they do not know how to act in situation that other people think are just ordinary. They feel inferior and want to get out of the situation. They also fell unhappy when people ask them personal questions in public or when they talk to someone in a superior position. Shy people behave differently from more confident people. So, it is clear that shy people are afraid or reluctant to speak or make conversation in English with friends in front of the class.

Many factors influence students' shyness. The first consideration about his might focus on why people are shy according to psychologist.

J-SHMIC, Vol 3, No 2, August 2016
According to Lyness (2013) Shyness is partly a result of genes a person has inherited. It's also influenced by behaviors they've learned, the ways people have reacted to their shyness, and life experiences they've had. Below are some factors:

a. Genetics.

Our genes determine our physical traits, like height, eye color, skin color, and body type. But genes also influence certain personality traits, including shyness. About $20 \%$ of people have a genetic tendency to be naturally shy. But not everyone with a genetic tendency to be shy develops a shy temperament. Life experiences also play a role. It means that a person inherits shyness from the parents, that is, the person is born with this personality characteristic because the parents were shy.

\section{b. Life experiences.}

When people are faced with a situation that may lead them to feel shy, how they deal with that situation can shape their future reactions to similar situations. For example, if people who are shy approach new things little by little, it can help them become more confident and comfortable. But if they feel pushed into situations they don't feel prepared for, or if they are teased or bullied, it can make them even more shy.

The examples other people set can also play a role in whether a person learns to be shy or not. If the parents of a shy child are overly cautious or overprotective, it can teach the child to back away from situations that
The Relationship between Shyness and Motivation to Speak English of the First Year Students of English Study Program of FKIP UIR Pekanbaru 
might be uncomfortable or unfamiliar.

In connection to this, shy people learned to be shy when they were children because their parents did not encourage them to be more confident. The parents probably comforted and given them extra attention when they acted shy, so the children learned that being shy was a good way to get extra love and attention. Shy people have exaggerated feelings about themselves. They are very concerned about their outward behavior, their feelings of selfconsciousness, and their physical symptoms of shyness. They do not want their weaknesses to be known by others.

According to Lyness (2013) new and unfamiliar situations can bring out shy feelings - like the first day of school, meeting someone new, or speaking in front of a group for the first time. People are more likely to feel shy when they're not sure how to act, what will happen, how others will react, or when all eyes are on them. People are less likely to feel shy in situations where they know what to expect, feel sure of what to do or say, or are among familiar people. Like other emotions, shy feelings can be mild, medium, or intense - depending on the situation and the person. Someone who usually or often feels shy might think of himself or herself as a shy person. People who are shy may need more time to get used to change. They might prefer to stick with what's familiar.

That's why People who are shy often hesitate before trying something new. They often prefer watching others before joining in on a group activity. They usually take longer to warm up to new people and situations.Sometimes being quiet and introverted is a sign that someone has a

J-SHMIC, Vol 3, No 2, August 2016 naturally shy personality. But that's not always the case. Being quiet is not always the same as being shy.

\section{Self-Concept}

Shy people will be influenced by their selfconcept. Gagne (1990) states self-concept is the perception that we have about ourselvesour attitude toward ourselves, the language we use to describe ourselves.

Mc Donald and Federick (1976) define that the self-concept will change with an individual's experiences. The selfconcept probably changes throughout life. Since shy people is interacting with other people at every stage in his life, he frequently receives description of himself from other people. She or he is ashame if other people know her or his weaknesses. In addition, Centi (1993) states that the students who have negative self-concept would influence their life. They only focus on their weaknesses. They usually force to make negative comparison with others and fell down in doing something. Person who sees himself friendly but find himself in a group that is unfriendly to him may infer that he is unfriendly and that the unfriendliness of the group is a response to his own disagreeableness.

That's why in speaking, we need to practice our English in front of the class or in many ways whether it is perfect or not, because "practice makes perfect". We should not be shy to speak and afraid to communicate with others. We need to practice in speaking in order to make our English perfect. According to Lyness (2013) many people want to reduce their shyness. But people who are naturally shy also have gifts that they might not appreciate in themselves. For example, because shy people may prefer listening to talking, they sometimes become really good listeners

The Relationship between Shyness and Motivation to Speak English of the First Year Students of English Study Program of FKIP UIR Pekanbaru 
(and what friend doesn't appreciate that?!).People who are shy might also become sensitive to other people's feelings and emotions. Because of their sensitivity and listening skills, many people with a shy personality are especially caring toward others, and interested in how others feel. People often consider them the finest friends.Of course, some people want to feel less shy so they can have more fun socializing and being themselves around others. If you're trying to become less shy, it can help to:

\section{a. Overcoming shyness takes}

practice. People who are shy tend to give themselves fewer chances to practice social behaviors. It's no wonder that people who shy away from socializing don't feel as socially confident as those who are outgoing they have less practice! The more you practice social behaviors, the easier they get, and the more natural they feel for you.

\section{b. Take slow, steady steps}

forward. Going slow is OK. But be sure to go forward. Stepping back from any situations that might trigger you to feel shy can reinforce shyness and keep it at a level that's hard to get past. Build confidence by taking one small forward step at a time.

c. It's OK to feel awkward. Everyone does sometimes. People who are shy are often afraid to feel awkward or uncomfortable. But don't let that keep you from doing what you want. You might feel awkward asking your crush for a first date. That's perfectly natural. Whether your crush says yes - or no is out of your control. But not asking at all means you'll never get that date. So go for it anyway! d. Know that you can do it. Plenty of people learn to manage their shyness. Know that you can, too. (Lyness, 2013)

\section{Be True to Yourself}

We cannot change our true inner nature (and who would want to?). If you have a naturally shy style, or if shyness holds you back, you might have to work at developing a sense of ease around new people.Most people find that the more they practice socializing, the easier it gets. Practicing social skills - like assertiveness; conversation; and friendly, confident body language - can help people overcome shyness, build confidence, and get more enjoyment from everyday experiences.

Speaking is an activity which gives an opportunity to practice a language. However, the students still do not have motivation to speak English. They are still shy in a presence of other.

According to Scott as quoted by Kerlinger et al (1987) Motivation means a process of stimulating people to action to accomplish desired goals. In this term, motivation to speak means to motivate the students to speak English with their friends to accomplish their desired goals.

Ausubel and Robinson as quoted by Chastain (1976) said that there are three components in achievement motivation in the school (campus), they are:

a. Cognitive drive involves the need to know and understand one's surroundings

b. Ego-enhancement consists of the individual's need for a sense of adequacy and self-esteem

c. Affiliation denotes individual's need for social approval from their group

The Relationship between Shyness and Motivation to Speak English of the First Year Students of English Study Program of FKIP UIR Pekanbaru 
In addition, Dobson (1974) states that motivation is commonly thought of as an inner drive, impulse, emotion or desire that move one to a particular action. Each aspect can arouse one's motivation in doing something, especially in speaking English. In the same way, Morgan (1961) said that motivation is very important in learning and it is also an aid for learning because it produces variables behavior, and certain of this can become associated with the situation in which the behavior takes place.

Hammer (1990) as quoted by Ariani suggested that in studying the target language, there are two types of such motivation, integrative and instrumental motivation. 1) integrative motivation is employed when learners wish to integrate themselves into the culture of the target language community, to identify themselves with and become a part of that. 2) instrumental motivation describes a situation in which learners believe that he mastery of the target language will be instrumental in getting them a better job position or status.

Shyness is as a part of personality is one of the dominant factors that can obstruct speaking activity. Some students who are studying English do not speak English because they are shy to speak the language. They are afraid of making a mistake in speaking. Another reason that they are shy to speak is that they did not speak first, they always wait for their friends to speak first so

J-SHMIC, Vol 3, No 2, August 2016 that they seldom speak each other because mostly they have the same idea.

In addition, Dobson (1974) said that when students asked to converse, speak quietly that they can scarcely be heard. It means that the students who feel shame in speaking will speak in low voice because they can scarcely be heard.

\section{METHOD}

This research is a descriptive quantitative. The research involves collecting data in order to answer questions concerning the status of the subject of this study (Gay, 1987). The writer focused on the relationship between students' shyness and their motivation to speak in speaking English. So, there are two variables in this research. They are independent (students' shyness) and dependent (motivation to speak) variable. It was conducted at the English Study Program of FKIP UIR Pekanbaru which is located on Jl. K.H. Nasution. The time of research was on September until April 2015.

The population of this research is all of second semester students of English Study Program of FKIP UIR Pekanbaru. There are six classes. The total number of the population is around 212. The reason for taking the first semester students as the subject of this research is based on the writer's observation that some of those students tend to be shy to express their ideas in speaking.
The Relationship between Shyness and Motivation to Speak English of the First Year Students of English Study Program of FKIP UIR Pekanbaru 
Table 1

The distribution of Population of the Second Semester Students of English Study Program of FKIP UIR Pekanbaru

\begin{tabular}{|c|c|}
\hline Class & $\begin{array}{c}\text { Number of } \\
\text { students }\end{array}$ \\
\hline 2 A & $\mathbf{2 6}$ \\
\hline 2 B & $\mathbf{2 6}$ \\
\hline 2 C & 27 \\
\hline 2 D & 24 \\
\hline 2 E & 25 \\
\hline 2 F & $\mathbf{2 6}$ \\
\hline TOTAL & $\mathbf{1 5 4}$ \\
\hline
\end{tabular}

Sample is finite part of a statistical population whose property, are studied to gain information about the whole (Webster, 1985). Arikunto (2012) states if the population is homogeneous enough, for the population that less than 100 person the sample is taken $50 \%$, but the population is more than 100 persen the sample is taken $15 \%$ of them. So, the amount of students who was a sample of this research was 25 students. The writer took the sample randomly.

Table 2. The Score of Questionnaire

\begin{tabular}{|l|l|l|l|}
\hline Positive Statement & Score & Negative Statement & Score \\
\hline Strongly Agree & 5 & Strongly Agree & 1 \\
\hline Agree & 4 & Agree & 2 \\
\hline Undecided & 3 & Undecided & 3 \\
\hline Disagree & 2 & Disagree & 4 \\
\hline Strongly Disagree & 1 & Strongly Disagree & 5 \\
\hline
\end{tabular}

Table 3. The Indicators of Students' Shyness

\begin{tabular}{|l|l|l|l|}
\hline \multirow{2}{*}{ No } & \multicolumn{1}{|c|}{ The Aspect of Shyness } & \multicolumn{1}{|c|}{ Items } \\
\cline { 3 - 4 } & & \multicolumn{1}{|c|}{ Positive } & \multicolumn{1}{c|}{ Negative } \\
\hline 2 & $\begin{array}{l}\text { Worry about other think of } \\
\text { them }\end{array}$ & $\begin{array}{l}\text { Become shy to deal with } \\
\text { people from a different social } \\
\text { class or to work with more } \\
\text { skilled people }\end{array}$ & $8,9,10,11,5,6,7$, \\
\hline 3 & $\begin{array}{l}\text { Avoid social gathering and } \\
\text { usually speak in low voice }\end{array}$ & $12,13,14,15$ & 18 and 20 \\
\hline
\end{tabular}

The instrument was questionnaire to know students' shyness and motivation to speak. To measure the students' shyness, the writer used five categories, which asked an individual to respond to a series of statements by indicating strongly agree, agree, undecided, disagree and strongly disagree, as in the following table: 
To know the students' motivation to speak English, the writer also gave questionnaire. There were four categories in this research used,
3 (often), 2 (sometimes), 1 (seldom) and 0 (never). The indicator of students' motivation to speak as in describe in the following table:

Table 4. The indicators of students' motivation to speak

\begin{tabular}{|l|l|l|}
\hline No & Aspect of Motivation & Items \\
\hline 1 & Integrative Motivation & $1,2,3,4,5,6,7,8,9,10,11,12$, \\
\hline 2 & Instrumental motivation & $13,14,15,16,17,18,19,20$ \\
\hline
\end{tabular}

The data collection technique used in this research collecting by the writer would given 20 items in each questionnaire to the students. In this items included of students' shyness and motivation to speak in answering the questionnaire.

The procedures to conduct the data are as in the following:

a. Ask the student to read instruction on the paper questionnaire sheet carefully with do not forget write their name.

b. The writer remind them about answering the question/statement based on theirselves behavior in daily life.

c. Ask the student choose the available answer from possibilities below:

a).Questionaire for students' shyness:

$\begin{array}{ll}\text { SA } & \text { : Strongly Agree } \\ \text { A } & \text { : Agree } \\ \text { DA } & \text { : DisAgree } \\ \text { SDA } & \text { : Strongly DisAgree }\end{array}$

b) Questionnaire for Students' motivation to speak:

$\begin{array}{ll}\text { SA } & : \text { Often } \\ \text { A } & : \text { Sometimes } \\ \text { U } & : \text { Seldom } \\ \text { DA } & : \text { Never }\end{array}$

d. Give time about 60 minutes for students to do the questionnaire.

e. Collect the students' answer sheet.

f. Check the students' answer sheet and then analyze them.

This research was to analyze the relationship between shyness and motivation to

J-SHMIC, Vol 3, No 2, August 2016 speak. To test the hypothesis the following stages were conducted: to test whether the variables are linear or non linear, dependent or independent, finding out regressiion value. In order to find out the relationship between the students' shyness and their ability in speaking the the following formula are used:

$$
\mathrm{r}=\frac{\mathrm{n}\left(\sum \mathrm{XY}\right)-\left(\sum \mathrm{X}\right)\left(\sum \mathrm{Y}\right)}{\sqrt{\mathrm{n}\left(\sum \mathrm{X}^{2}\right)-\left(\sum \mathrm{X}\right)^{2} \mathrm{n} \sum \mathrm{Y}^{2}}-\left(\sum \mathrm{Y}\right)^{2}}
$$

\section{FINDING AND DISCUSSION}

This research was conducted to know the relationship between two variables, namely, the students' shyness as the independent variable (X) and the students' motivation to speak English as the dependent variable (Y).

The score of the independentand dependent variable ( $\mathrm{X}$ and $\mathrm{Y}$ ) is obtained from the students' answer in questionnaire. The questionnaire is about the students' shyness that is indicated by three ; indicators, they are: worrying about what others think of them, dealing with people from a different social class or work with more skilled people, and avoiding social gathering. To know the students' motivation to speak English that is indicated by two indicators, they are integrative and instrumental motivation.

After obtaining all data concerning the students' shyness and their motivation to speak English, the data are analyzed statistically. The following tables present and clarify the data of both variables.

The Relationship between Shyness and Motivation to Speak English of the First Year Students of English Study Program of FKIP UIR Pekanbaru 
The Score of Students' Shyness

\begin{tabular}{|l|l|l|l|}
\hline No. & Indicators & $\begin{array}{l}\text { Positive (Strongly } \\
\text { Agree+ Agree) }\end{array}$ & $\begin{array}{l}\text { Negative (Strongly } \\
\text { Disagree + Disagree) }\end{array}$ \\
\hline 1 & $\begin{array}{l}\text { Worry about what others think of } \\
\text { them }\end{array}$ & $55 \%$ & $45 \%$ \\
\hline 2 & $\begin{array}{l}\text { Become shy to deal with people from } \\
\text { a different social class or to work with } \\
\text { more skilled people }\end{array}$ & $40 \%$ & $60 \%$ \\
\hline 3 & Avoid social gathering & $25 \%$ & $75 \%$ \\
\hline \multicolumn{2}{|l|}{ Percentage } & $40 \%$ & $60 \%$ \\
\hline
\end{tabular}

From the table, it can be noticed that only $40 \%$ of the respondents acknowledge that they were "shy".

To determine the degree of the relationship between variable $X$ and variable $Y$. The result of the computation of " $r$ " is 0.90 . Since the table value at the level 0.05 with 28 the degree of freedom (0.3809) is less that calculated value $(0.90)$, the writer concludes the research hypothesis is accepted. It indicates that there is significant relationship between students' shyness and their motivation to speak English. The degree of the relationship between the two variables is determined by coefficient correlation of $\mathrm{r}^{2}$, that is $(0.90)^{2}=0.81$ or $81 \%$.

\section{CONCLUSION}

Based on the data analysis presented in the previous chapter, the writer draws some conclusions as follows :

a. From the data analysis, it can be concluded that there is significant relationship between students' shyness and their motivation to speak English. The coefficient determination of $r^{2}$ is $0.81 \%$. This means that $81 \%$ of students' motivation to speak is influenced by

J-SHMIC, Vol 3, No 2, August 2016 their shyness. It indicated that, the higher the level of shyness, the lower motivation to speak and the lower the level of shyness, the higher the motivation to speak English will become.

b. Only $40 \%$ of the respondents that were indeed "shy".

c. Some of the students become shy to deal with people from a different social class or to work with more skilled people and worry about what others think of them . This observable from the percentage of it is the highest among the three indicators of shyness.

\section{REFERENCES}

Bowen. J. Donald. 1985. Tesol Technique and Procedure. Heinle and Heinle Publisher. A Division of Wodsworth, Inc. Boston

Coffield, F et al. 2004. Learning Styles and Pedagogy in Post-16 Learning: A Systematic and Critical Review. London: Cromwell Press Ltd

Dobson. Julia. M. 1974. Effective Teaching for English Conversation Groups.

The Relationship between Shyness and Motivation to Speak English of the First Year Students of English Study Program of FKIP UIR Pekanbaru 
Newbury House Publisher. Washington D.C

Ellington, Henry et al. 1996. How Students Learn - A Review of Some of the Main Theories: Activists, Reflectors, Theorists and Pragmatists.Aberdeen, Scotland: The Robert Gordon University

Farhady and Hatch. 1982. Research Design and Statistics for Applied Linguistics. Newbury House Publisher, Inc. Rowley.

Gay. LR. 1990. Educational Research. Competences for Analysis and Application. Third Edition. Florida International University

Guilford JP. 2000. Psycometric Method. Tosho Printing Co. LTD. TokyoJapan

Huda, Miftahul. 2013. Model-Model Pengajaran dan Pembelajaran: Isu-isu Metodis dan Paradigmatis. Yogyakarta: Pustaka Pelajar

Nasution, S. 2008. Berbagai Pendekatan Dalam Proses Belajar dan Mengajar. Jakarta: Bumi Aksara.

Nunan, David. 1991. Language Teaching Methodology. Prentice Hall. Sydney

Rizqi, Achmad. 2013. Gaya Belajar Siswa SMK PIRI 1 Yogyakarta. Fakultas

J-SHMIC, Vol 3, No 2, August 2016
Teknik Uniersitas Negeri Yogakarta

Slameto. 2010. Belajar dan Faktor-faktor yang Mempengaruhinya. Jakarta: Rineka Cipta

Sugiono. 1998. Metode Penelitian Administrasi. CV. Alfabet. Bandung

Thobroni, M and Arif Mustofa. 2011. Belajar dan Pembelajaran: Pengembangan Wacana dan Praktik Pembelajaran dalam Pembangunan Nasional. Jogjakarta: Ar-ruzz Media

Widdowson. H. 1978. Teaching Language as Communicate. Oxford University Press

Zimbardo,, Philip G.; Ferreras, Anthony; Brunskill, Sarah R. "Social Intensity Syndrome: The Development and Validation of the Social Intensity Syndrome Scale". Journal of Personality and Individual Difference. 2014

ZoltaÂn DoÈ rnyei. 2001. Motivational Strategies in the Language.CAMBRIDGE UNIVERSITY PRESS. Cambridge, New York, Melbourne, Madrid, Cape Town, Singapore, São Paulo
The Relationship between Shyness and Motivation to Speak English of the First Year Students of English Study Program of FKIP UIR Pekanbaru 